\title{
Obtaining International Sovereignty of the UPR at the Central Rada Period
}

\author{
Uzyskanie suwerenności na arenie międzynarodowej przez URL \\ w okresie Centralnej Rady
}

\section{- Abstrakt •}

Historia dyplomacji i polityki zagranicznej nowych niepodległych państw jest jednym z najtrudniejszych obiektów badań, ponieważ łączy w sobie złożone kwestie z zakresu historii świata oraz danego narodu. Istnienie służb dyplomatycznych jest jednym z najważniejszych atrybutów każdego niepodległego państwa, wskaźnikiem rzeczywistych aspiracji kraju, jego stanowiska wobec świata oraz jego ideologii politycznej. Ostateczne powodzenie rewolucji ukraińskiej w latach 1917-1920 zarówno na wschodzie, jak i na zachodzie kraju naszym zdaniem zależało od jej nagłośnienia za granicą oraz uzyskania znacznego wsparcia z zewnątrz, tak jak miało to miejsce np. w przypadku Polski, Finlandii czy państw bałtyckich.

Działania podjęte przez Ukraińską Centralną Radę w celu stworzenia wszech-rosyjskiej federacji przyniosły skutek przeciwny do oczekiwanego - doprowadziły do konfliktu zbrojnego z władzami radzieckimi i zwrócenia się o wsparcie niemiecko-austriackich wojsk w walce z bolszewicką agresją. W dłuższej perspektywie błędem okazało się podjęcie w styczniu 1918 r. przez Centralną Radę decyzji o opo-

\section{- Abstract •}

The history of diplomacy and foreign policy of new independent states are one of the most difficult and hardest objects of scientific study because they synthesize complex issues of world and national history system components. The diplomatic service is one of the most important attributes of any sovereign state, an indicator of real aspirations of the country and of its attitude towards the world and its political content. The ultimate success of the Ukrainian revolution of $1917-1920$ both in the East and in the West, in our opinion, depended on the international publicity and receiving substantial external support as it happened for example in Poland, Finland and the Baltic States.

Measures on the formation of an all-Russian federation taken by the Central Rada led to the opposite result - the armed conflict with red Petrograd and invitation of the German-Austrian troops to save the UPR from the Bolshevik aggression. In the long term the foreign policy choice made by the Central Rada in January 1918 in favor of Germany and its allies, that were defeated in World War I, was a mistake. At the same time, signing the Brest peace treaty be- 
wiedzeniu się po stronie Niemiec, które zostały pokonane w trakcie I wojny światowej. Niemniej jednak podpisanie Traktatu pokojowego w Brześciu pomiędzy URL a Państwami Centralnymi i uznanie dyplomatyczne Ukrainy przez te państwa stworzyło nowe możliwości rozwoju narodowej służby dyplomatycznej i konsularnej oraz zmusiło RFSRR do podjęcia negocjacji pokojowych z Ukraińską Republiką Ludową.

Słowa kluczowe: uznanie dyplomatyczne, niepodległość, traktat pokojowy, państwo, wojna tween the UPR and the Central Powers and diplomatic recognition of Ukraine from these states opened new opportunities for the development of national diplomatic and consular service, and forced RSFSR to agree to start peace talks with the Ukrainian People's Republic.

Keywords: diplomatic recognition, independence, peace treaty, state, war

As is well known, the February democratic revolution in 1917 made Russia ideologically and politically more attractive to the liberal-democratic regimes of the Entente. But the creation of the Central Rada was virtually unnoticed by the Western democracies, Ukrainian national liberation movement (like Finnish, Belarusian, Latvian or Lithuanian) was perceived solely as a German-Austrian creation aimed at weakening of the Entente and the USA. Indicative in this respect was the publication in "Action Française" on 5 May 1917, which noted: "This refers primarily to the preservation of Russia's new national unity. This applies also to the fact that it was not crushed and remained «united and indivisible». The worst danger threatening the Russian revolution - is separatism... Ukrainian separatism - has long been one of the German hopes" (Kosik, 2004).

Indeed, during 1917 - early 1918 the Entente's main task in the East Europe was to preserve the front against Germany and Austria-Hungary, which was under threat of collapse because of the revolutionary events in Russia. The democratic West obviously underestimated the ability of the Bolsheviks to seize power in Petrograd and keep it, extending to the outskirts. On the other hand, the Entente Powers, to some extent, were interested in establishing contacts with the Central Rada, because activation of anti-war sentiment in post-revolutionary Russia considerably weakened and complicated its military and strategic objectives in the West.

True, on 11 March 1917 at a reception of ambassadors of Great Britain, France and Italy Foreign Minister of the Provisional Government P. Milyukov reiterated the government policy on strict adherence to international treaties signed by Tsarist Russia and the agreements that follow from it. On 23 March in an interview for journalists, he called for "liberation of the Slavic peoples inhabiting in 
Austria-Hungary", creation of Czech-Slovak and Serbo-Croatian states as well as for merger of Habsburg's Ukrainian lands with Russia and taking control of Constantinopole and the Black Sea straits. This somewhat reassured official Paris and London, who considered their duty to help the "democratic" Russia to continue war on the Eastern Front, because when it probably will come out of the war and German divisions will transfer from the Eastern Front to the West, the course of the First World would definitely be settled in favor of the Central Powers. American troops in Europe can give the desired effect only in spring of 1918, and by that time the Allied powers will make anything to retain the Eastern Front.

In addition, the Entente Powers had little awareness of the Ukrainian national movement (with the exception of a handful of scientists), and any particular opinion about Ukraine was hard to make, because even its leaders did not have a unified concept of the liberation process. Interest of the Entente in the events in Ukraine began to grow in April 1917 when the National Congress in Kyiv was held and made its decision to fight for the autonomy of Ukraine in the Russian Federation. The Entente hoped that Kyiv will remain its ally in the war against Germany and Austria-Hungary, especially in view of weakening Russian troops' combat capability and morale, Ukrainianized departments look more decent.

No wonder that the French Foreign Ministry officials on 5 May 1917 formally asked the head of the Office of Policy and Trade: "Should the separatist tendencies of Ukraine be encouraged, even implicitly?". The answer was evasive: "At this point we have to show themselves liberal about that case". But the Department of Europe of the same Foreign Ministry five days later lifted the ban on the distribution of the Union for the Liberation of Ukraine Lausanne monthly - L'Ukraine. A little later, French Ambassador in Switzerland - J.-B. Bo - sent the brochure "Ukrainian nation and its requirements" issued by the Central Office for Nationalities to the Foreign Ministry.

It was a report of the Ukrainian delegation at the third Conference of nationalities in Switzerland, which once again reminded that "the Russian rights on Ukraine are the same as the rights of the German Empire on Belgium or Holland", or even as the French rights on Franconia. Then the booklet said: "The Ukrainian nation like all others has the right to exist and firmly believes in the noble words of Lord Winston Churchill: "We want this war to correct the map of Europe on a national basis, by real desire of the peoples living in these territories... We seek durable peace that restores harmony, liberates races, and is focused on the integrity of nations".

However, ambassador J.-B. Bo with the utmost frankness formulated a negative attitude to events in Ukraine in the cover letter to the Foreign Affairs minister 
A. Ribot: "We hope that Ukrainian propaganda has no deep roots in Russia and that the Provisional Government will take the necessary measures to prevent the spread of the movement, which could be extremely dangerous if it will be propagandized in a wide and rich regions of South" (Kosik, 2004).

Thus, the existence of an independent or even autonomous Ukraine was unacceptable to the leadership circles of the Entente, at least until the power in Petrograd was in the hands of the democratic Provisional Government and maintained hope of keeping control over the situation in Russia, and consequently - the Eastern Front against Germany and its allies. But after the US joined World War I on 6 April on the side of the Entente, it would be imprudent for the Central Rada to link its fate with countries doomed to military defeat. Its chairman - M. Hrushevsky, moreover, well understood that the reactionary (in comparison with the Russian Provisional Government) governments of the Central Powers did not contribute to profound social and economic reforms, especially regarding agriculture.

Therefore, the first foreign-policy views the Central Rada for a long time were focused on the Entente Powers. In the summer of 1917 direct contacts were initiated, when military representatives of the Entente began to arrive to Kyiv. The first to visit the Central Rada in July 1917 was the Japanese embassy attaché in Petrograd, Ashida. In view of this, anti-Ukrainian policy of democratic Russia as the main Entente's accomplice seems strange. V. Vynnychenko frankly said about this in an interview with correspondent $\mathrm{S}$. Obac for the newspaper L'Intransigeant (Paris) during the second trip to Petrograd in late July 1917.

This interview has gained a lot of publicity both in Ukraine and in Russia and abroad as the head of the General Secretariat V. Vynnychenko after the statement that the Ukrainian "national liberation desire equally strong as tsarist yoke was odious", and that 3 million Ukrainian soldiers of the Russian army must "only defend Ukraine", dared to answer the most critical questions that concerned the Entente. French journalist asked V. Vynnychenko: "It is rumored that Germany is allegedly feeding the Ukrainian separatist movement" and heard an adequate response of the Ukrainian leader: "This is more than untruth. This is absurd. We have received more than one million rubles from the Ukrainian living in Russia alone. But the truth is that the more the Russian government opposes our legitimate demands, the more some Ukrainians change their views on AustriaGermany. I will not conceal that sitting in our Rada there is a certain amount of Germanophiles. But they are so small that you can not take them into account" (Kosik, 2004).

The last statement of V. Vynnychenko provoked sharp criticism from the leadership of the Central Rada, and in Petrograd it was used to warn the allies and per- 
suade them not to support Ukrainian movement and to incite against it Russian opinion. V. Vynnychenko categorically denied that he spoke about the existence Germanophiles among the members the Central Rada, the French censorship initially is not even allowed to publish the interview in full, but the French ambassador in Petrograd J. Noulens in detail informed his MFA about the interview.

With reference to the central organ of the Cadet Party - daily newspaper Rec', which published the answers of V. Vynnychenko in the extended version (in view of complete absence in Russia at that time of any censorship), the French ambassador drew the attention of the leadership that seems the interviewer "claims that his countrymen have serious claims against France and England, which in the past were indifferent to the demands of Ukraine. This error can be corrected only when the two allied states declare and ensure the right to Ukrainian national autonomy". Ambassador was struck by the fact that the head of the General Secretariat finished his interview by the aphorism of the famous French psychologist and social theorist of "era of the masses" - G. Le Bon: "Ignoring the psychology of nations - the cause of most political mistakes" (Kosik, 2004).

French Foreign Minister became acquainted with information of J. Noulens and insisted on sending on a mission to Ukraine the founder of the Central Office for Nationalities - known international journalist and 33 degree mason of lodge "The Great East of France" J. Pelissier. He had to gather information about the Ukrainian national movement and travelled from Petrograd to Kyiv on 16 (29) August before leaving for handing in the newspaper L'information article about Ukraine.

Journalist noted in it: "Among us, some political and diplomatic circles stubbornly denied until recently that there is some Ukrainian question, or at least not recognized the importance of this movement, which was declared artificial, lacking roots in the country and created by the Germans. Hopefully the higher spheres do not share this problem, rumors and blindness and that our attitude to this new state was planned advisedly. Whether we like it or not, Ukraine is a historical, geographical, ethnographical and social fact which we must consider" (Kosik, 2004).

J. Pelissier reacted to his task with great responsibility and on the basis of materials collected in Kiev did serious political and sociological analysis - The Ukrainian question and after return to Petrograd presented it to the French ambassador J. Noulens on 2 (15) September. To the report journalist-spy has added series of documents, including an interview with representatives of the Central Rada, materials about ethnic borders of Ukraine, the church's role in the national liberation movement, information about national and party composition of the Central 
Rada, as well as documents translated into French. Unfortunately, the political department of the French Ministry of Foreign Affairs did not receive the report until early December, when the military-political situation in the UPR became dramatically worse.

Yet, the trip of J. Pelissier, who became the first "lawyer" of Ukraine in France, was a kind of "breakthrough" by which the French official circles began to gradually give up the position of a neutral observer. Ukraine began to be given a closer look as a "new force in the East", and it was not by chance that representative of the British Embassy in Petrograd - Professor Pire appeared at the same time in Kiev. On 10 (23) September J. Pelissier organized in Petrograd an informal meeting between general secretary of international affairs O. Shulhyn and J. Noulens during which the Ukrainian representative requested the support of the Entente. The Frenchmen showed interest in the Ukrainian events, offered financial and technical assistance for Ukraine to continue the war against the Central Powers, but J. Noulens opposed the autonomy of Ukraine and advised not to complicate the situation around the Provisional Government.

Soon head of the French military mission in Russia - Brigadier General H. Niessel came to Kyiv. Having a negative attitude to "the Ukrainian question", he refused to visit the General Secretariat, but the Ukrainian ministers which interested in Entente's support met with general in the French Consulate. Consequently, on behalf of $\mathrm{H}$. Niessel in Kiev a French representative remained at the headquarters of the Southwestern Front - Brigadier General J. Tabouis that had to maintain constant communication with the General Secretariat. It is significant that both generals noticed the weakness of the Central Rada in insufficient communication with the masses and therefore advised to immediately hold general elections to the Ukrainian parliament. But the Ukrainian socialist parties representatives who mostly formed the Central Rada under various pretexts delayed this.

On 26 September general and high-ranking mason J. Tabouis along with Colonel Perlye met S. Petliura and had a two-hour conversation about the Ukrainization of Army. Then the Entente's militaries still in doubt impressed by the failure of Kornilov's mutiny and with increasing concern observe the intensification of the revolutionary crisis in Russia, which promised almost inevitable catastrophe at the front in the near future. So they in advance began to "build bridges" with the forces that after disintegration of state-ally have become islands, which can be expected in the case of continuing the war.

In this context, it is necessary to consider the meeting between J. Noulens and the General Secretary of Finance, prominent Ukrainian economist M. TuganBaranowsky, held in mid-October of that year in Petrograd. It was about granting 
Ukraine by the French private entrepreneurs loans for the purchase of military equipment. However, leaders of the Central Rada have suspected "some evil venture of the French capitalists" and not taken advantage of this offer. The strong commitment expressed in the $3^{\text {rd }}$ Universal of the Central Rada "to the establishment of peace as soon as possible. For this we take strong measures to force through the Central Government allies and enemies to immediately begin peace talks" (Nova rada, 1917, November 8) could not but cause concern of the Entente.

After the Bolsheviks came to power in Petrograd, ties between the Central Rada and the Western powers increased significantly. First, the principles fixed in the $3^{\text {rd }}$ Universal generally meet the interests of Allies, because they separated the UPR from Lenin's government, while declaring loyalty to a federal democratic Russia, and this was what the Western Allies wanted to see. Although during the Soviet era the official opinion was that the Entente Powers sought the dismemberment of Russia and supported "the Ukrainian bourgeois nationalists", in fact it was the opposite.

Secondly, the refusal of the Central Rada and the General Secretariat to recognize Leninist People's Commissars as the legal Russian government and initiative to create it on the non-Bolshevik basis were regarded by the Western diplomacy as an opportunity for understanding in the fulfillment of allied commitments to continue the war and to block Petrograd's anti-peace initiative.

Third, establishment of contacts with leaders of the Ukrainian movement proceeded not only via official channels but also "on Masonic lines". Well aware of the backstage history of the Ukrainian revolution P. Khrystiuk noted that "when the government of Kerensky fell, Entente's representatives in Kiev did well to took Ukrainians; among other things to lay on its side Ukrainian, they set «in work» between some Ukrainian circles even «francs». Pronounced «ententefeels» obtained at the time no small amount" (Hristûk, 1921).

Thus, from beginning of its existence the UPR got into the epicenter of world politics and became one of the most attractive objects of international diplomacy. A struggle of the Central Rada for the creation of federal government in Kyiv was closely intertwined with the problem of peace with the Central Powers, to some extent, even has been subordinated to the latter, because Ukrainian leadership long hoped that such an authoritative "all-Russian Center" would conclude a just peace "without annexations and contributions".

Not by chance, in the resolution of Kyiv's Congress of the Peoples, held on 8-14 September 1917, it was clearly stressed that Russian republic should be declared federal and democratic and realize these principles in its structure. Full, immediate declaration of its federation is able to bring clarity to the nature and 
state of war, and will provide the opportunity to conclude an honorable peace, to which all nations aspire.

A sharp change in the position of the Entente that before was negative and even hostile to the idea of Ukrainian statehood, believing that it will damage the unity of the Eastern Front and cause for allies unnecessary trouble, can be very simply explained. The interest of the Soviet Russia and the Central Powers in stopping the war unbearable for both sides sooner or later had to lead to a separate peace, therefore the Entente was ready to support the UPR if it would further restrain the Austro-German troops.

When on 20 November 1917 the Bolsheviks took control over Headquarters of the Supreme Commander in Mogilev, military missions of Great Britain, France, Italy, Japan, Romania, Serbia and Belgium moved to Kyiv, where their heads expressed their willingness to help the UPR by people, arms and finances to hold the front against the Central Powers. At the same time, the Croatian units formed from prisoners of war on the territory of Kiev and Odessa military districts (24000 people) agreed to join the Ukrainian army.

According to the plan for further campaign in the East, drawn up by allies, Romania had to cooperate with Ukraine, the Don and the North Caucasus, and with national troops formed in rear that the Allies had hoped to gather. Plans of the Allied representatives concerning the UPR were limited to creating a few Ukrainian corps, which together with the Czechoslovak regiments, formed of Austrian prisoners and mobilized Czech colonists from Ukraine, and the Poles had to take important strategically points on the Romanian and the South-Western fronts.

The Entente was not too concerned about the lack of Ukraine's state independence declaration. And the UPR leadership, especially V. Vynnychenko, S. Petliura and $\mathrm{O}$. Shulhyn time to time actively maintained contacts with foreign emissaries, stimulated their activity. So, in mid-November 1917, J. Tabouis along with British major have visited $\mathrm{O}$. Shulhyn and reported that the allies, above all France, with great sympathy relate to the cultural and political revival of Ukraine, its efforts to build a democratic republic, and therefore offer assistance. However, General Secretary of international affairs rather firmly said that the key to establishing and developing contacts with France and in general with any state is official recognition of the UPR.

S. Petliura, in turn, boastfully promised during meetings with the Allies on 26 November and 13 December to send an army of 500 thousand to the front, though perhaps he himself could not say exactly what were the real forces his government had at its disposal. Not taking into account those scientists who consider army of the Central Rada as all Ukrainian troops presented at the Military 
Congress, or the formation of those who endorsed the resolution of devotion to Ukrainian case, data here range from 70 to 400 thousand: 180 thousand in the South-Western and the Romanian fronts, 150 thousand - in the rear garrisons and 60 thousand of free Cossacks (Soldatenko, 2007).

Thus, the two largest European and world democracies allegedly recognized the sovereignty of the Ukrainian state at a time when its socialist leaders were unable to renounce the idea of federation with Russia. Historical destiny, at first glance, gave a unique opportunity to the Ukrainian people. But the prospects continued to die because the interests of allies were not favorable for Ukrainians both in the front and rear. The problem was only in what way to achieve peace, because after the Bolshevik coup in Petrograd, which was a success largely due to skillful anti-war propaganda, doubts in this fallen away.

In addition, the Central Rada gave itself ahead towards peace talks initiative to the Council of People's Commissars. While various Ukrainian congresses carried the resolution on the need for immediate "democratic peace", the Bolsheviks simply offered the Germans to begin negotiations on its conclusion. The fact that the Entente Powers, represented by its ambassadors in Petrograd did not react to the note of the Soviet Russia on 8 (21) November with a proposal to declare a truce on the front and begin peace talks, and acting Commander in Chief Lieutenant General M. Duhonin, contrary to the relevant order, abandoned such contacts with the German command.

So Lenin in the morning of the next day sent to all regiments of the army a telegram calling for soldiers and sailors to take the cause of peace in their hands. To Ukrainian leaders in those extreme conditions opened two ways: fight for peace "independently" or go to it by common, collective efforts. The choice was made in favor of the second option, but since the Central Rada and the General Secretariat did not recognize Lenin's government as the central government of Russia, the utopian project of the UPR leadership had no chance be embodied in life and, conversely, only aggravated relations with Lenin's government, which from the first day considered itself the rightful ruler of Russia.

The leaders of military missions from the UK, France, Italy, Japan and Romania with headquarters in Mogilev, despite the dismissal of M. Duhonin, on 10 (13) November gave him the collective note of protest against the violation of the British-Russian-French agreement from 5 September 1914, which forbade the allies a separate peace or truce. The former commander in chief sent the text of the document to all commanders and to fronts and organized talks in Mogilev (involving representatives of the UPR - D. Doroshenko and O. Lototsky) on the formation of an alternative all-Russian government. 
Thus, the Central Council turned for Lenin's People's Commissars in one more link of "the All-Russian counterrevolution", whose defeat was only a matter of time. At that time, driven to despair and cut off from the whole world by blockade of the British-French fleet Germany and Austria-Hungary wanted to get rid of trouble in the East. The Central States desperately lacked the strategic raw strength at the rear, sufficient food and human resources that the Entente had in excess after the US entry into the war with their Latin American allies.

In the spring of 1917 the Foreign Minister of Austria-Hungary O. Chernin wrote prophetically to Emperor Charles I: "In late summer or in autumn peace should be made at any price. If monarchs of the Central Powers can not in the coming months sign a peace agreement, the peoples pass over through their heads and wave of revolutionary processes will sweep everything on its way". German Crown Prince Wilhelm demanded from his father in the summer of 1917: "We need... for every thing to try to conclude a separate peace with Russia" (Hornykiewicz, 1967).

However, Emperor Wilhelm II led the so-called "Military group", which planned to defeat the revolutionary Russia by short strike and impose peace on the German terms. Then all the forces could be turned against France and Great Britain, because Prussian militarists in summer 1917 demanded: "On Petersburg!". "Frankly, - confessed later Chief of General Staff General Field Marshal P. Hindenburg, - I'm very pleased to have completed this" (Vospominaniâ Gindenburga, 1922). However, a competing group of industrialists, who tried to hide the violent nature of peace in the East and to facilitate thus the German diplomatic game in the West, on 19 July provided the adoption of resolution on peace in the Reichstag. In an extremely vague form it recommended to conclude peace which was "incompatible with forcible acquisition of territory and political, economic or financial oppression” (Ercberger, 1923).

When representatives of the parliamentary parties came with this resolution to Wilhelm II, he told MPs that he approves desire of the Reichstag to sign "a peace by agreement", although such words in the text were absent. They were willfully made to the previous draft resolution by Hindenburg deputy - Colonel General E. Lyudendorff, and the Emperor explained the reason for his satisfaction: peace by agreement means that "we will take from the enemies money, raw materials, cotton, and oil out of their pockets to our pockets" (Ercberger, 1923).

The time for this has come when the Bolsheviks seized power in Petrograd, moreover, on the Western Front decisive battles for the German army were brewing that required concentration of forces. "Needless to say, - wrote Hindenburg, - that in talks with the Russian government of terror very few answered to my 
political beliefs. But first of all we had to sign an agreement with the existing rulers of Great Russia. However, there were all uncertain that I personally do not believe in the long reign of terror" (Vospominaniâ Gindenburga, 1922).

On 27 November Germany formally agreed with Lenin's proposal to start peace talks; on 2 December Chancellor G. Hertling in a speech in the Reichstag declared that the peace initiative of People's Commissars is acceptable as a basis. The next day started negotiations in Brest-Litovsk (now - Brest in Belarus).

Meanwhile, on 5 (18) December V. Vynnychenko and O. Shulhyn during talks with British officers and J. Tabouis in exchange for their agreement to continue the war again demanded de-jure recognition by the Entente of Ukrainian statehood and establishment of diplomatic relations (although, according to the $3^{\text {rd }}$ Universal, the UPR was proclaimed, "not separating from the Russian Republic and preserving its unity"). In addition delegates of the Central Rada A. Halip and Ye. Holitsynsky who have been sent to negotiate with the Entente to Jassy (Romania) refused to recognize the UPR's share of the external debt of the tsarist government (Hornykiewicz, 1967).

But even greater distrust and anxiety in the Entente than the preservation of the Russian state unity was caused by the declaration of the Central Rada that the main direction of the UPR diplomacy was to achieve universal peace without annexations and indemnities, based on recognition of the right of nations to self-determination. The note of such content was approved on 9 (22) December by Minor Rada and sent by the General Secretariat to all belligerent and neutral States on 11 (24) December. The paper also noted that the UPR "stands on the path to independent international relations until national federal authorities will be created in Russia”.

Germany and its allies, unlike the Entente, already on 13 (26) December agreed on participation "of the UPR plenipotentiaries" in the Brest Peace Conference. "The State Secretary von Kühlmann and I, - wrote Major General Max Hoffmann in his memoirs, - happily received Ukrainians, because their statement allowed us to use this new delegation against delegation of Petersburg" (Kedrin, 1928).

These forced steps of the Central Rada led to a rupture of relations with the Entente, and then repeatedly used by anti-Ukrainian forces to discredit the Ukrainian People's Republic on the West. In addition, measures of the Central Rada on formation of an all-Russian federation led to the opposite result: armed conflict with red Petrograd and invitation of the German-Austrian troops to save the UPR from the Bolshevik aggression. In the long-term perspective foreign policy choices made by the Central Rada in favour of Germany and its allies which were defeated in World War I, was a mistake. 
But at the same time concluding the Brest peace treaty between the UNR and the Central Powers on 27 January (9 February) 1918 and diplomatic recognition of Ukraine by those states opened new opportunities for the development of national diplomatic and consular service, forced the Soviet Russia to agree to start peace talks with the UPR and provided a favorable position for Kyiv in the Ukrainian-Belarusian negotiations on the state border. Ukraine is gradually transformed into an attractive center for the newly independent nation states and state formations on the territory of the former Russian Empire.

\section{References:}

Vêdênêêv, V. V., \& Budkov, D. V. (2006). Unist' ukraïns'kö̈ diplomatï. Stanovlennâ zovnišn’opolitičnoï službi Ukraïns'koü deržabi. 1917-1923 roki. Kiïv: K. I. S.

Vinničenko, V. K. (1991). Zapovit borcâm za vizvolennâ. Kï̈v: Vidavniče tovaristvo "Krinicâ". Vospominaniâ Gindenburga. (1922). Moskva: Misl'.

Golovčenko, V. I., \& Soldatenko, V. F. (2009). Ukrä̈n'ke pitannâ v roki Peršoü svitovoü vijni. Kiïv: Parlaments'ke vidavnictvo.

Gruševs'kij, M. (1991). Hto taki ukraïnci i čogo voni hočut'. Kiïv: Tovaristvo “Znannâ” Ukraïni.

Dorošenko, D. (2007). Mö̈ spomini pro nedavnê minule (1914-1920 roki). Kïv: Tempora.

Kedrin, I. (ed.). (1928). Berestejs'kij mir: spomini ta materiali. Z nagodi 10-h rokovin. 9.II.1918 - 9.II.1928. L'viv-Kiïv: Červona kalina.

Коsiк, V. (2004). Franciâ ta Ukraïna. Stanovlennâ ukrä̈n'kö̈ diplomatï (berezen'1917-lûtij 1918). L'viv: Vidavničij centr LNU imeni Ivana Franka.

Kuraêv, O. O. (2006). Ukraïn'ka prolema upolitici Berlina ta Vidnâ u Peršijsvitovij vijni (1914-1918). Kiïv: Institut ukraïns'koï arheografiï ta džereloznavstva im. M. S. Gruševs'kogo.

Nova rada, 1917, 8. November.

Soldatenko, V. F. (2007). Vinničenko i Petlûra: politični portreti revolûcijnoj dobi. Kiïv: Svitoglâd.

Solovjova, V. V. (2006). Diplomatična diâl'nist' ukraïns'kih nacional'nih urâdiv 1917-1921 rr. Kiïv: Institut istoriï Ukraïni NAN Ukraïni.

Hristûk, P. (1921). Zamitki i materiâli do istorï ukraïns'kö̈ revolûcï. 1917-1920 rr, 4, 1. Viden: Ukraïns'kij sociologičnij institut.

Ercberger, M. (1923). Germaniâ i Antanta: memuari. Moskva-Petrograd: Gosizdat.

Borowsky, P. (1970). Deutsche Ukrainepolitik 1918 unter besonderer Berücksichtigung von Wirtschaftsfragen. Historische Studien. Lubeck-Hamburg: Matthiesen.

Hornykiewicz, T. (1967). Ereignisse in der Ukraine 1914-1922. Deren Bedeutung und historische Hintergründe. Bd. 2. Philadelphia-Horn: W. K. Lypynsky East European Research Institute.

Remer, C. (1997). Die Ukraine im Blickfeld deutscher Interessen. Ende des 19. Jahrhunderts bis 1917/18. Frankfurt/Main-Berlin-Bern-New York-Paris-Wien: Verlag Peter Lang. 